\title{
Er det umagen værd?
}

på een af de workshops, som blev afholdt på konferencen "Kvinnor $i$ akademin" på Chalmers Tekniska Högskola, Göteborg, den 20. - 22. august. Og det er et godt spørgsmål, set i lyset af nogle af de resultater, som blev præsenteret på konferencen, som drejede sig om kvinders karrieremuligheder indenfor naturvidenskabelig, teknisk og medicinsk forskning. En undersøgelse af det svenske Medicinsk Forskningsråds ansættelse af forskerassistenter dokumenterer: "For at en kvindelig forsker skal kunne opnå samme kompetence score som en mandlig kollega, er hun nødt til at overgå hans videnskabelige produktion med ... ca. tre ekstra papers i Nature eller Science, eller 20 ekstra papers i ... et anerkendt specialtidsskrift."l (egen oversættelse). Undersøgelsen var promptet af en konstatering om, at $44 \%$ af ansøgerne til forskerassistentstillinger indenfor det medicinske område var kvinder, men kun 20\% af stillingerne gik til kvinder.

Men sådan går det vel ikke til herhjemme? Og dog! En undersøgelse af adjunktansættelser på det Naturvidenskabelige fa- 
kultet på Københavns Universitet i årene 1987 - 1996 viser, at der blandt ansøgerne var $16 \%$ kvinder, blandt de kvalificerede var der $14 \%$ kvinder og blandt de, som blev ansatte var der $8 \%$ kvinder. $^{2}$

Myten, om at køn og magt er uvæsentlige størrelser i (natur)videnskabens herligt objektive, neutrale og vardifrie verden, lever i bedste velgående i manges bevidsthed, til trods for at ovenstående resultater gennemhuller denne myte. Netop spørgsmålet om magt blev taget op i et oplæg af psykolog Mona Eliasson fra Uppsala Universitet. Hun havde undersøgt institutionskultur, og de ansattes holdninger til køn og magt på 3 forskningsinstitutioner med mere end $40 \%$ kvindelige Ph.D.-studerende, det vil sige miljøer, hvor kvinder ikke kan siges at være et særsyn. Hvor de mandlige forskere på alle niveauer minimerer betydningen af de eksisterende magtrelationerne, accepterer dem - ja, dårligt nok ser dem, er de kvindelige forskere på alle niveauer, det vil sige også de kvindelige professorer, meget bevidste om disse relationer og finder det meget ubehageligt at skulle indgå i magtrelationerne.

Mona Eliassons forklaring er, at strukturerne er skabt af mænd og for mænd kvinder har kun haft adgang til universitetets verden de sidste ca. 100 år, og derfor opfattes manden stadig som normen og kvinden som afvigeren - den anormale. Når kvinderne så kommer ind og gør krav på stillinger, opstår der konflikter og derved synliggøres magtrelationerne. Men magten bagatelliseres, dels fordi selvopfattelsen på universiteterne er, at det er demokratiske institutioner, dels fordi universiteterne ikke har viljen til forandring. Et par illustrative citater fra Mona's undersøgelse: "Vi har så mange kvinder her, at det er ved at være et problem" - sagt af en mand på en institution med $47 \%$ kvinder. Udspurgt om adfærd i forbindelse med et uryddeligt laboratorium svarer den mandlige Ph.D.: "Jeg sørger for der bliver ryddet op" (underforstået:
"Det sætter jeg laboratorieassistenten til"), mens den kvindelige Ph.D. svarer: "Jeg rydder op".

Et andet spændende indlæg "Hvad er et godt forskningsmiljø?" blev holdt af den danske arkitekt Birgit Cold, som er professor på Norges Teknisk- Naturvidenskabelige Universitet. Svaret på spørgsmålet indeholder bl.a. stikordene: Tværfaglighed, nysgerrighed og åbenhed, inddragelse af brugerne og formidling til ikke-eksperter, selvkritik og social og faglighed tryghed, og mest vigtigt i denne sammenhæng - et miljø præget af både mænd og kvinder på alle niveauer. En interessant pointe i Birgit's indlæg var en påpegning af, at de forskningspolitiske tendenser $\mathrm{i}$ tiden (færre og større miljøer, hyppige evalueringer etc.) faktisk på mange punkter modvirker opbygning af gode forskningsmiljø .

Konferencen sluttede med en paneldiskussion "Visioner for fremtiden og inspiration til fortsat arbejde", hvori bl.a. deltog universitetsdirektør Anne Grete Holmsgaard, DTU og den svenske undervisningsminister Carl Tham. Anne Grete Holmsgaard mente ikke, at vi har tid til at vente på at kønsbalancen indfinder sig af sig selv - det vil tage mange år - og på grund af aldersfordelingen indenfor universiteterne vil der ske en stor udskiftning af personale i løbet af de næste 10 - 15 år. Denne opfattelse deltes af Carl Tham, som sagde at der kræves tryk udefra - men også vilje og ønske indefra - for at forandre universitetsverdenen. Han fortalte, at annonceringen af de såkaldte Tham-professorater (30 professorater forbeholdt kvinder) havde fremkaldt mange nyttige diskussioner om ansættelser i akademia. Således berettede han om modtagelsen af et brev fra ledelsen ved et svensk universitet, som havde spurgt om det dog ikke var et lidt for drastik initiativ - kunne man ikke bare besætte stillingerne som sædvanligt, dvs. ved at formulere stillingsopslagene med henblik på en bestemt person og derefter nedsætte "det rigtige" bedømmel- 
sesudvalg. Netop uigennemskueligheden og den manglende ansvarsplacering $\mathrm{i}$ ansættelser var et emne, som mange kom ind på i diskussionen, og et af Anne Grete Holmsgaard's forslag til forandring gik da også ud på at arbejde for en ændret ansættelsesprocedure. Andre forslag drejede sig om at vedblive med at afdække de kønsdiskriminerende mekanismer indenfor universitetsverdenen, at dokumentere med løbende statistikker hvorledes situationen udvikler sig og at afæske de ansvarlige, det vil sige, de som har magten, forklaringer og redegørelser for hvad der sker/ikke sker på området.

Jytte Hilden's initiativ: FREIA-programmet, kan, hvis det ellers vedtages i Folketinget, rette lidt op på situationen herhjemme i Danmark, men som sagt: Der er også behov for en positiv indstilling og en forandringsvilje indefra - fra de (mænd), som pt. sidder på magten. $\mathrm{Og}$ så kan vi måske nå en situation, hvor svaret på spørgsmålet i titlen er et klart: JA! - hvor de kvinder, som har lysten og evnen til at gå ind $\mathrm{i}$ disse områder, ikke skal kæmpe mod urimelig forskelsbehandling, men kan bruge deres kræfter på at præge den tekniske og naturvidenskabelige forskning - til gavn for alle i samfundet.

\author{
Mona Dahms, lektor \\ Institut for Elektroniske Systemer \\ Aalborg Universitet
}

\section{Noter}

1. "Nepotism and sexism in peer-review", Christine WennerDs and Agnes Wold. I Nature, vol. 387, 22. maj 1997, side 341-343.

2. "Establishing the facts. Women in science in Denmark”, Flemming M. Nicolaisen, prodekan, Københavns Universitet. EADS VII, Wroclaw, 1997. 